\title{
Anthophyllite asbestos: state of the science review
}

\author{
Shannon H. Gaffney ${ }^{a *}$, Matthew Grespin ${ }^{b}$, Lindsey Garnick, \\ Derek A. Drechsel' ${ }^{b}$ Rebecca Hazanc, Dennis J. Paustenbach ${ }^{\text {d }}$ \\ and Brooke D. Simmons ${ }^{\mathrm{a}}$
}

\begin{abstract}
Anthophyllite is an amphibole form of asbestos historically used in only a limited number of products. No published resource currently exists that offers a complete overview of anthophyllite toxicity or of its effects on exposed human populations. We performed a review focusing on how anthophyllite toxicity was understood over time by conducting a comprehensive search of publicly available documents that discussed the use, mining, properties, toxicity, exposure and potential health effects of anthophyllite. Over 200 documents were identified; 114 contained relevant and useful information which we present chronologically in this assessment. Our analysis confirms that anthophyllite toxicity has not been well studied compared to other asbestos types. We found that toxicology studies in animals from the 1970 s onward have indicated that, at sufficient doses, anthophyllite can cause asbestosis, lung cancer and mesothelioma. Studies of Finnish anthophyllite miners, conducted in the 1970s, found an increased incidence of asbestosis and lung cancer, but not mesothelioma. Not until the mid-1990s was an epidemiological link with mesothelioma in humans observed. Its presence in talc has been of recent significance in relation to potential asbestos exposure through the use of talc-containing products. Characterizing the health risks of anthophyllite is difficult, and distinguishing between its asbestiform and non-asbestiform mineral form is essential from both a toxicological and regulatory perspective. Anthophyllite toxicity has generally been assumed to be similar to other amphiboles from a regulatory standpoint, but some notable exceptions exist. In order to reach a more clear understanding of anthophyllite toxicity, significant additional study is needed. Copyright $\odot 2016$ John Wiley \& Sons, Ltd.
\end{abstract}

Keywords: anthophyllite; toxicity; mesothelioma; asbestos; asbestiform; Finland; mining; talc

\section{Introduction}

Anthophyllite is an amphibole form of asbestos that has historically been mined in small quantities around the world, most notably in Finland, as well as in Japan, Australia, South Africa, the United States, and several countries (Bowles, 1955). Worldwide mining and the use of anthophyllite has been limited compared to more common commercially available asbestos. Anthophyllite use is estimated to have accounted for only about $0.25 \%$ of total asbestos use from 1900 until 2003 (Virta, 2005). Compared with commercial asbestos types that are more easily fiberized, spun and transformed into marketable products, anthophyllite uses have been and remain limited (Bowles, 1955).

Despite their relatively limited use overall, anthophyllite fibers have been used as far back as $2500 \mathrm{BC}$ to strengthen pots and cooking utensils in Finland (Huuskonen et al., 1980). However, anthophyllite was not formally described until 1801, when a mineralogist named Schaumacher discovered the mineral in Norway, and named it after the Greek word 'clove' in reference to its color. Since then, it has been studied, characterized, and distinguished from its relatives by its distinct optical and structural properties. The crystallography was identified by its unique cleavage angle in 1892, and by X-ray in 1930. The latter has remained the most reliable method for identifying the mineral. Continuing into the $1930 \mathrm{~s}$, other properties including the density, specific gravity, chemical composition and typical fiber dimensions of anthophyllite, were also described. However, the presence of other co-occurring mineral fibers and impurities in many anthophyllite deposits made early attempts at chemical analyses difficult (Rabbitt, 1948; Bowles, 1955).

Anthophyllite occurs naturally as a grey, greenish grey, or white mineral, whereas individual fibers appear white when uncontaminated (Bowles, 1955). Its molecular formula is $\mathrm{Mg}_{7}\left(\mathrm{Si}_{4} \mathrm{O}_{11}\right)_{2}(\mathrm{OH})_{2}$; however, the relative content of $\mathrm{MgO}, \mathrm{CaO}$ and iron varies by the geographic location of deposits. Owing to its chemical nature, anthophyllite demonstrates a high resistance to chemical reactions, making it relatively inert and stable in the presence of acid and heat (Bowles, 1955). As a result, and despite its relatively limited use overall, anthophyllite was sometimes used in consumer products including laboratory materials such as acid filters and combustion tube stoppers, as well as a component in cements, plastic flooring, insulation, roofing materials, wall plasters and as a filler material in rubber, in battery boxes, and in other electrical insulation products (Bowles, 1955; Huuskonen et al., 1980).

*Correspondence to: Shannon H. Gaffney, Cardno ChemRisk, 101 2nd St., Suite 700, San Francisco, CA 94105, USA.

E-mail: shannon.gaffney@cardno.com

${ }^{a}$ Cardno ChemRisk, San Francisco, CA 94105, USA

${ }^{b}$ Cardno ChemRisk, Boulder, CO 80301, USA

${ }^{C}$ Department of Epidemiology, University of Michigan, School of Public Health, Ann Arbor, MI 48109, USA

${ }^{d}$ Cardno ChemRisk, Jackson, WY 83002, USA 
Anthophyllite can occur in both an asbestiform or non-asbestiform character (Roggli and Coin, 2004). Specific analytical techniques have to be employed to distinguish whether or not the measured anthophyllite is asbestiform or non-asbestiform. While other forms of asbestos, such as chrysotile, amosite and crocidolite, have separate names for their non-asbestiform counterparts (e.g. serpentine, grunerite and riebeckite, respectively), both asbestiform and non-asbestiform anthophyllite are referred to merely as 'anthophyllite' (ATSDR, 2001). As such, the word asbestos is often added after the mineral (e.g. 'anthophyllite asbestos') to specify that the asbestiform variety of the mineral is being referenced (ATSDR, 2001). Figure $1 A$ and $B$ consists of photographic images of asbestiform anthophyllite fibers and non-asbestiform anthophyllite cleavage fragments (Fig. 1C).

Asbestiform and non-asbestiform anthophyllite may occur together within the same mineral deposits. However, they can be distinguished by their structural characteristics and pathogenic properties (Mossman, 2008). In general, asbestiform refers to thin, flexible and strong crystallized fibers, whereas non-asbestiform refers to thick, short and weak fragments that break along a cleavage plane (Fig. 1). Animal studies have indicated that the cleavage fragments of non-asbestiform minerals are less pathogenic and less bioreactive than asbestiform minerals (Mossman, 2008).

Few studies have investigated the degree of exposure or health effects associated with exposure to pure anthophyllite, probably because of the limited sources and uses of anthophyllite compared to other, more common fiber types. Anthophyllite is regarded as a non-commercial amphibole, and is primarily considered a contaminant of more widely used minerals, such as chrysotile, vermiculite and talc (Roggli and Coin, 2004). The available studies on anthophyllite provide limited information regarding its toxicity, and the results of toxicology and epidemiology studies over time have been largely equivocal from a human health perspective. To our knowledge, no published resource exists that offers a full understanding of the contemporaneous toxicological, epidemiological and regulatory atmosphere regarding anthophyllite specifically. The purpose of this study was to perform a comprehensive review regarding these topics from a state-of-the-art standpoint, and to place that within the context of asbestos research in general.

\section{Methods}

We conducted a comprehensive search of publically available documents that directly or indirectly discussed anthophyllite use, mining, properties, toxicity, exposure potential and potential health effects. Several database search engines including PubMed, ToxNet and Web of Science were used to identify relevant reports, peer-reviewed literature, or government documents. Toxicology and industrial hygiene text books were also considered. Through the search, we determined that large amounts of anthophyllite asbestos were historically mined at a specific location in Paakila, Finland; therefore, search terms relevant to mining asbestos in Finland were also included. Searches included combinations of the following terms: anthophyllite, anthophyllite asbestos, anthophyllite mining, anthophyllite talc, Finland, Finnish, Paakila and Paakila mine. The review was limited to literature in English, unless translations from other languages were available.

We initially identified 236 potentially relevant toxicology, epidemiology, occupational or medical publications. Papers identified were deemed relevant if they discussed anthophyllite toxicology, potential for exposure resulting from mining or end product use, regulatory or guidance exposure limits over time, or epidemiological studies examining health outcomes associated with exposure. A review of this literature indicated that 118 papers were not relevant based on these inclusion criteria, or because they only briefly mentioned anthophyllite as a form of asbestos mineral, but did not discuss in detail the aforementioned topics. Fourteen papers in languages other than English for which translations were not readily available were also excluded. We reviewed the references cited in each selected paper in order to determine whether additional sources were available that may not have been discovered in our initial search.

Overall, 114 papers were included in our analysis and reviewed in depth. Our findings were categorized into different time periods based on the state of the knowledge during the relevant period.

\section{Results}

\section{State-of-the-Art from 1900 to 1960}

Relatively little was known regarding anthophyllite specifically during this period. However, knowledge of the relationship between asbestos exposure generally and disease evolved dramatically in the early and mid-20th century. Figure 2 represents a timeline of some of the key scientific studies and findings from this time period. The early literature focused on case reports of patients with severe lung diseases; the physicians generally attributed the illnesses to asbestos use in high-exposure manufacturing and textile plants, or to handling raw asbestos (Cooke 1924, 1927; Pancoast and Pendergrass, 1925; McDonald, 1927; Oliver, 1927). In 1924, Cooke described a woman who died of pulmonary fibrosis as a result of asbestos exposure (Cooke, 1924). However, not until the 1930s was a clear risk of developing asbestosis from inhalation of asbestos dust determined, as well as the discovery that duration of exposure and amount of dust inhaled were key factors for

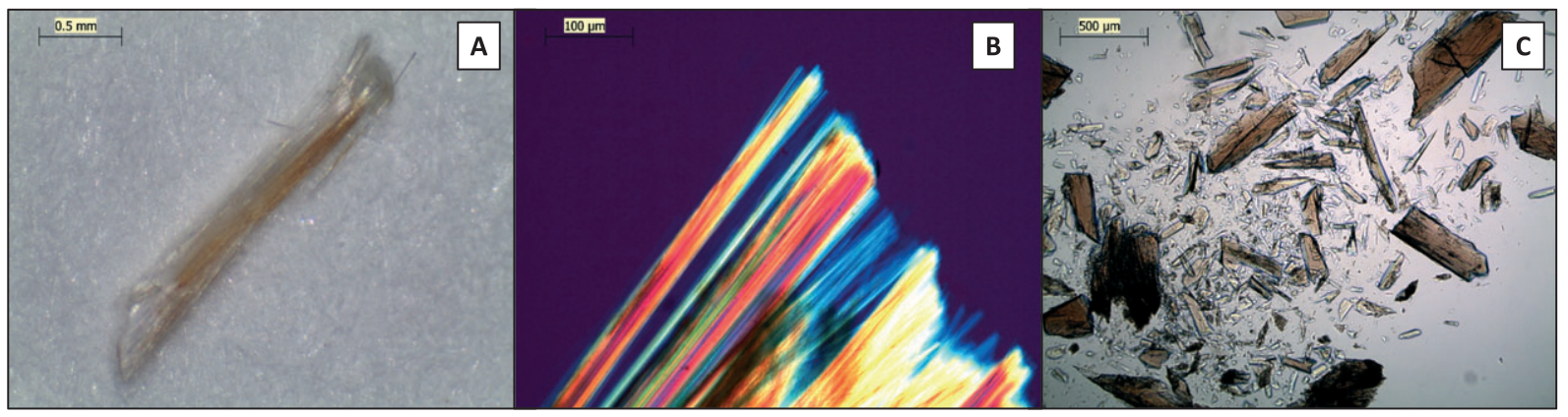

Figure 1. Asbestiform ( $A$ and $B$ ) versus non-asbestiform $(C)$ anthophyllite. 


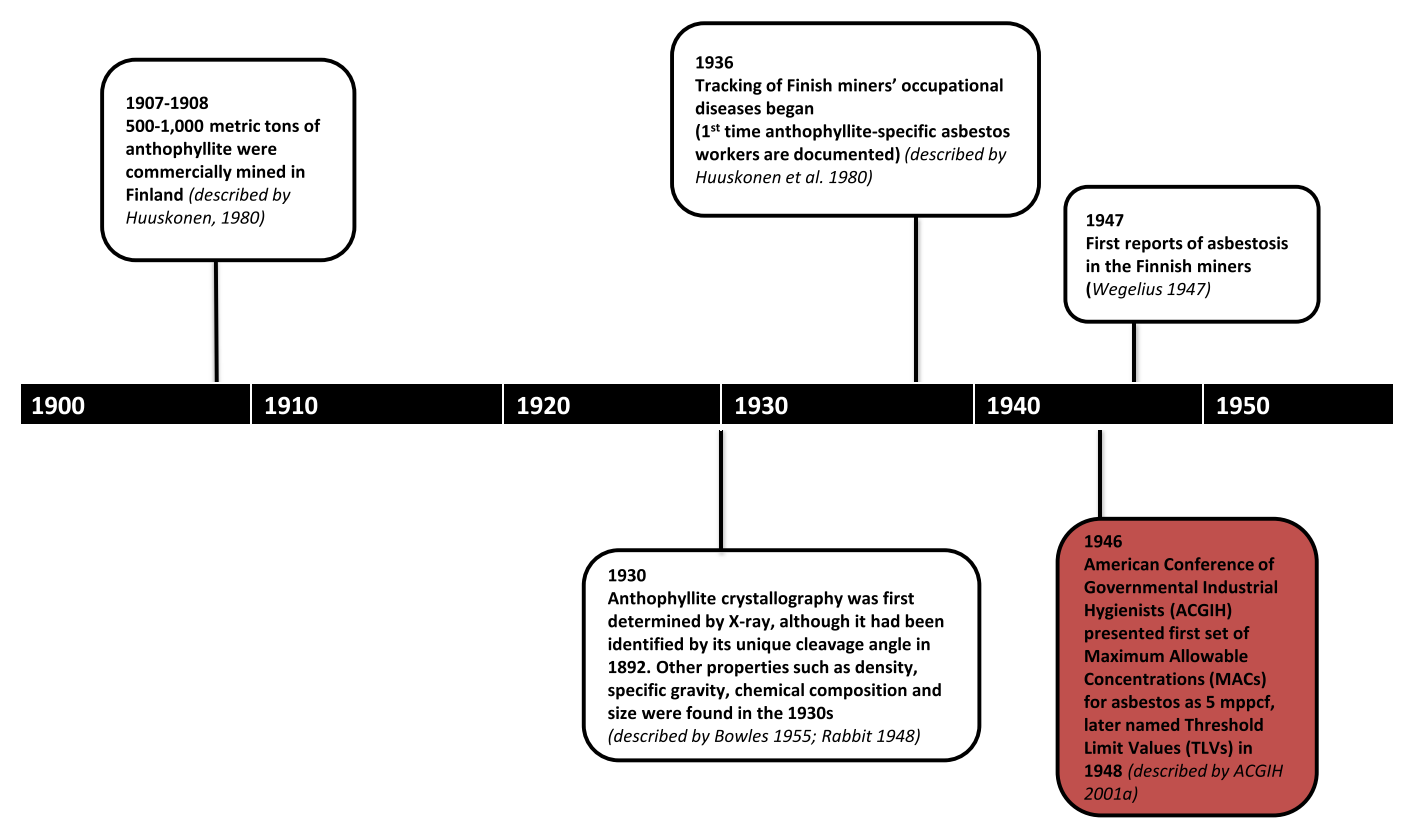

Figure 2. State of the science of anthophyllite from 1900 to 1960.

predicting disease (Cooke, 1924; Merewether and Price, 1930; Dreessen et al., 1938). As is true with respect to many later studies, these early studies did not distinguish different asbestos fiber types and there is little reason to suspect that significant exposure to anthophyllite occurred among these populations.

Studies of heavily exposed asbestos workers throughout the subsequent decades continued to focus primarily on workers in asbestos processing or manufacturing operations that used raw asbestos. Again, the asbestos fiber types were rarely, if ever, identified (Osborn, 1934; Wood and Gloyne, 1934; Fulton et al., 1935; Home Office, 1935; Lanza et al., 1935; Page, 1935; Donnelly, 1936; McPheeters, 1936; George and Leonard, 1939; Teleky, 1937; Brachmann, 1940; Stone, 1940; Doll, 1955). Occupational diseases, including those potentially associated with exposures to anthophyllite, were tracked in miners in Finland as early as 1936, when notification of occupational diseases became compulsory country wide. However, epidemiological evaluations of exposure and disease were not conducted until years later (Huuskonen et al., 1980). In 1947, Wegelius was the first to investigate cases of asbestosis in Finland, including some that were employed at the Paakkila mine in Finland (Wegelius, 1947). Although Wegelius made no specific reference to anthophyllite in his 1947 publication, the Paakkila mine is known to be an anthophyllite mine (Wegelius, 1947; Huuskonen et al., 1980). The author reported 34 cases of asbestosis, based on roentgen evaluations, in mine employees, and 92 cases of asbestosis in those working in a 'factory for finished products' (products not specified) (Wegelius, 1947: p. 143). Historically, those in asbestos mining, milling, and manufacturing settings, have been exposed to high concentrations [up to over $50 \mathrm{f} / \mathrm{cc}$ (Nicholson et al., 1979)] of airborne fibers. No additional studies from this time period that mentioned anthophyllite, or suggested exposure to anthophyllite at Paakkila or elsewhere, were identified.

\section{State-of-the-Art from 1960 to the mid-1970s}

Beginning in the early 1960s, significant progress was made toward understanding asbestos-related disease and, in particular, the potential health risk to workers involved in the insulation trades. Figure 3 represents a timeline of some of the key scientific studies and findings from this time period. Similar to earlier years, the majority of research focused not specifically on anthophyllite but on asbestos in general. In later years, however, focus turned toward chrysotile and other amphiboles, as researchers began to realize that the disease incidence seemed to vary by country, which was attributed to the different sources and types of asbestos used (Gilson, 1976; Gibbs and Berry, 2008). Epidemiological studies of potentially anthophyllite-related diseases did not begin until the latter portion of this time period.

The first epidemiological study associating asbestos exposure with mesothelioma appeared in 1960, and reported on mesothelioma incidence among South African crocidolite miners exposed through their work in the mines and from living in proximity to mining operations (Wagner et al., 1960). In 1965, Wagner published another study in which he reviewed mesothelioma cases in South Africa and the United Kingdom, which was among the earliest health-related studies to distinguish exposure by the different asbestos mineral fiber types. The authors found that although numerous cases of mesothelioma were reported in populations living or working near crocidolite mines, no cases were identified from similar areas near chrysotile mines (Wagner, 1965). These studies represented major developments in the knowledge regarding specific asbestos fiber type exposures as they related to neoplastic disease onset; however, anthophyllite was not discussed, nor was there reason to expect that these individuals would have been exposed to anthophyllite.

Although the majority of asbestos-related studies at this time did not discuss anthophyllite specifically, some information regarding anthophyllite asbestos and its potential health effects among certain occupational groups was suggested. It was during this period that researchers established a link between anthophyllite exposure and the presence of pleural plaques and asbestos bodies in lung tissue. As early as 1960, reports were made of pleural calcifications in those living in the vicinity of the Paakkila mine who had no known occupational asbestos exposures (Kiviluoto, 1965, 1960). In 1966, Meurman concluded that the asbestos bodies and pleural calcification seen in residents of the area surrounding 


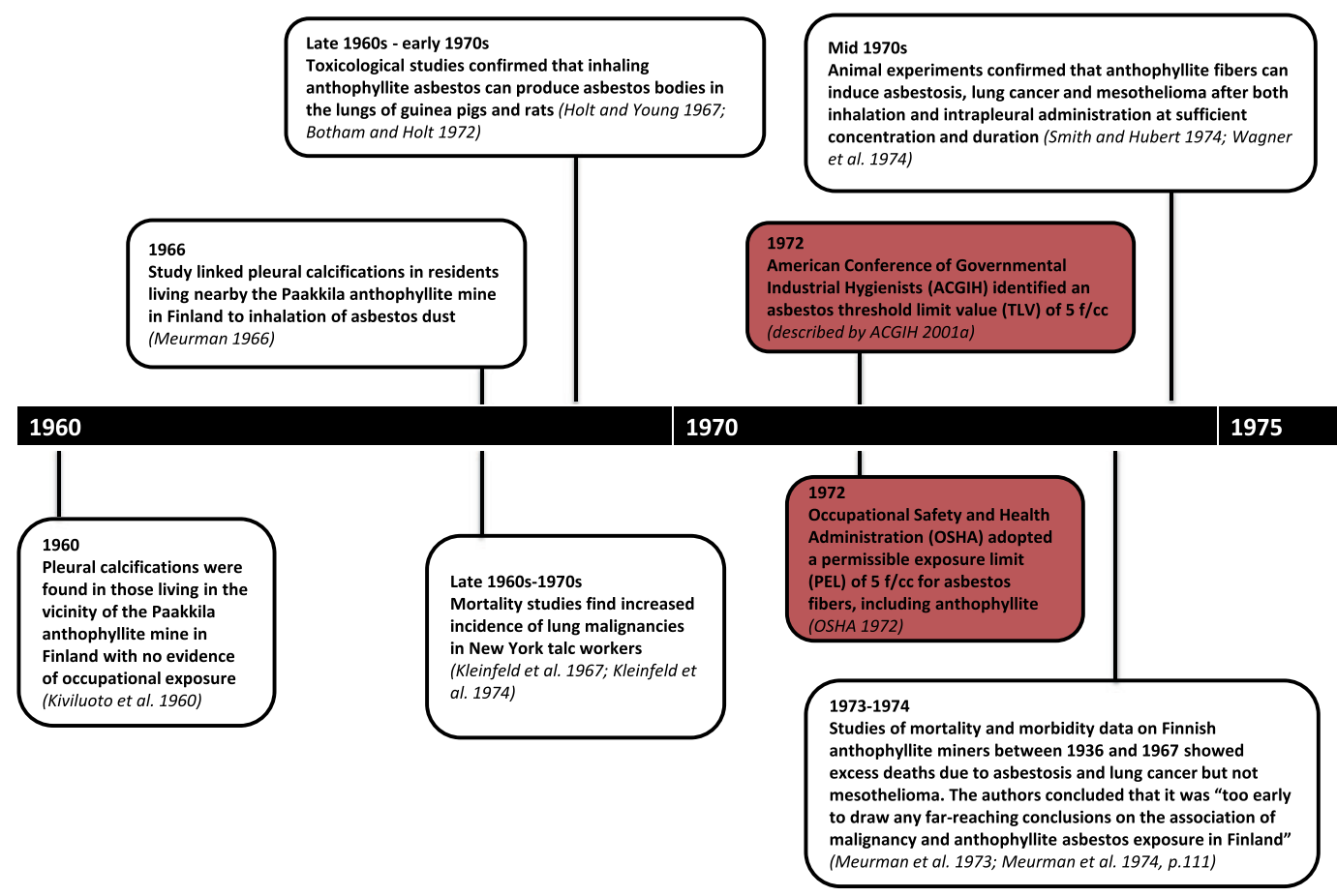

Figure 3. State of the science of anthophyllite from 1960 to the mid-1970s.

Finnish anthophyllite mines were as a result of inhalation of asbestos dust (Meurman, 1966). Similar findings were reported in 1966 by Raunio, who reported pleural calcifications among men and women living in the Tuusniemi commune in eastern Finland, the location of the Paakkila mine (Raunio, 1966). Raunio noted that although crocidolite was suspected of being a causative factor for mesothelioma at that time, there was no indication that anthophyllite could cause mesothelioma (Raunio, 1966). Raunio reported that although '[asbestos] dust [had] been spread over a rather extensive area for over 45 years', fewer cases of pleural tumors were reported among individuals living within the region in which pleural calcifications were more prevalent (i.e. near the Paakkila mine) as compared with a control population (Raunio, 1966: p. 46). Nurminen and Meurman and colleagues also collected mortality and morbidity data on Finnish anthophyllite miners who worked in the North Savo or Paakkila anthophyllite mines between 1936 and 1967 (Nurminen, 1972; Meurman et al., 1973; Meurman et al., 1974). Their 1973 and 1974 analyses of these data demonstrated a significant excess mortality from lung cancer, particularly for those with the most years of mining experience and the longest latency since first exposure. Meurman and colleagues noted, however, that the smoking histories of deceased workers were unavailable. The authors concluded that the small sample size of the study made it 'too early to draw any far-reaching conclusions on the association of malignancy and anthophyllite asbestos exposure in Finland' (Meurman et al., 1973; Meurman et al., 1974: p. 111). A few years later, Meurman et al. evaluated the same cohort but focused on workers who died between 1967 and 1977, and whose smoking habits were known. They reported a doseresponse relationship between increasing anthophyllite asbestos exposure and risk of lung cancer. They determined the relative risk of 3.3 for lung cancer in heavily exposed workers was significantly different than expected $(P<0.001)$; they noted that the relative risk among low to moderately exposed workers was 1.4 , but did not comment on significance (Meurman et al., 1979).
Several studies throughout the late 1960 s and 1970 s specific to anthophyllite miners and those in the surrounding communities failed to identify any cases of pleural or peritoneal mesothelioma (Noro, 1968; Kiviluoto and Meurman, 1970; Nurminen, 1972; Meurman et al., 1974). For example, Meurman's 1974 study considered 1092 anthophyllite miners and millers in Finland and reported excess mortality due to lung cancer and asbestosis, but noted that ' $\mathrm{n}] \mathrm{o}$ mesotheliomas were found in this series, and the possibility that they are hidden among the cancer cases is small' (Meurman et al., 1974: p. 110). In a 1976 review of asbestos-related cancers in various occupational groups and their comparative risks, Gilson noted that '[i]n the case of mesotheliomas there is evidence of a major effect of the fibre type in the order of risk, crocidolite $>$ amosite $>$ chrysotile $>$ anthophyllite' (Gilson, 1976: p. 113-114). This conclusion was largely drawn based on the Finnish studies showing that, at the time, no mesotheliomas resulting from exposure to anthophyllite alone had been reported, even with the significant doses received by anthophyllite miners and millers (Gilson, 1976).

In addition, Kleinfeld and colleagues conducted mortality studies on approximately 250 talc miners and millers from the upstate New York region during the late 1960s through the early 1970s (Kleinfeld et al., 1967; Kleinfeld et al., 1974). Talc ore mined in this region is unique in that it may contain significant amounts of both tremolite and anthophyllite (Virta 1989; Van Gosen et al., 2004). In both the original 1967 study and a follow-up in 1974, the authors found a nearly four-fold increase in the proportional mortality of the total deaths observed from lung and pleural malignancies in the study population: 11 observed versus 3.2 expected (Kleinfeld et al., 1967) and 12 observed versus 3.7 expected (Kleinfeld et al., 1974). However, the authors noted the lack of smoking data for the workers made it difficult to attribute increased lung cancer incidence to talc exposures (Kleinfeld et al., 1974). Furthermore, the authors noted differences in the affected age groups compared to the earlier occurrences of lung malignancies in 
asbestos insulators and mining cohorts exposed to 'pure anthophyllite' (Kleinfeld et al., 1974: p. 347). The authors postulated that this difference could result from two factors: (i) chrysotile to which asbestos insulators were exposed is more carcinogenic than the mixed dust consisting of talc, tremolite, and anthophyllite; and (ii) talc workers experienced lesser degrees of dust exposure compared to insulators and anthophyllite miners (Kleinfeld et al., 1974).

In addition to the growing number of occupational and environmental epidemiology studies, concurrent animal toxicology studies supported the assertion that exposure to anthophyllite asbestos resulted in formation of asbestos bodies in the lung. For example, Holt and Young $(1966,1967)$ found that anthophyllite fibers produced the 'largest and most characteristic asbestos bodies' in histological preparations of guinea pig lung tissue compared with chrysotile, amosite and crocidolite (Holt et al., 1966; Holt and Young 1967: p. 697). In the early 1970s, Botham and Holt (1972) extended this research, and found asbestos bodies in the lung tissue of guinea pigs and, to a lesser degree, in rats after inhalation exposure to pure Finnish anthophyllite.

\section{State of the Art from the mid-1970s to 1990}

Like other forms of asbestos, anthophyllite was not heavily regulated in the United States prior to the 1970s. Figure 4 represents a timeline of some of the key scientific studies and regulations from the late 1970 s to 1990 . From a regulatory perspective, anthophyllite asbestos has largely been grouped with other amphibole fibers, or with asbestos in general. In 1970 the United States Occupational Safety and Health Administration (OSHA) was established (U.S. Congress, 1970). In its initial 1972 standard, OSHA included anthophyllite fibers in its definition of asbestos, and established an 8-h permissible exposure limit (PEL) of $5 \mathrm{f} / \mathrm{cc}$ for fibers over 5 microns with a 3:1 aspect ratio. At this time, both asbestiform and non-asbestiform anthophyllite fibers, as well as all other types of asbestos fibers, were included under the standard (OSHA, 1972). In 1974, ACGIH lowered its TLV from 5 mppcf, or approximately $30 \mathrm{f} / \mathrm{cc}$, to $5 \mathrm{f} / \mathrm{cc}$ for all asbestos fibers $(\mathrm{ACGIH}$, 2001a).

Despite the general tendency to categorize asbestos types together during this time period, by the mid-1970s, additional research had been completed in an effort to further characterize and distinguish the structural and physicochemical properties of anthophyllite. Langer et al. (1974) used standard Union for International Cancer Control (UICC) fibers to investigate the dimensions of different types of asbestos by transmission electron microscopy (TEM), and reported that almost $40 \%$ of anthophyllite fibers were longer than $5.1 \mu \mathrm{m}$, compared to $16 \%$ of amosite and just $2 \%$ of crocidolite fibers (Langer et al., 1974). The mean width of anthophyllite and tremolite fibers was $0.37 \mu \mathrm{m}$, compared to $0.23 \mu \mathrm{m}$ for amosite and $0.20 \mu \mathrm{m}$ for crocidolite. The authors noted, however, that fibers wider than $1 \mu \mathrm{m}$ were not included in the analysis, which accounted for almost $7 \%$ of the anthophyllite fibers. As such, the calculated mean width for the anthophyllite fibers was 'very much less' than the actual width value (Langer et al., 1974: p. 70). Based on the fiber dimensions, the researchers concluded that the dust produced from milling or mining anthophyllite would contain substantially more countable fibers than would be observed from the same mass of crocidolite, which they believed had important implications for dust reduction methods relating to industrial hygiene (Langer et al., 1974). The study challenged the contemporaneous industrial hygiene standards by noting, 'exposure to 5 fibers/ml level results in a range of mass exposures which may vary almost a magnitude for the different amphibole types' (Langer et al., 1974: p. 79).

As the scientific and medical literature regarding the potential hazards of asbestos exposure advanced in the mid-1970s, OSHA lowered its PEL to $2 \mathrm{f} / \mathrm{cc}$ in 1976 (OSHA, 1976). While OSHA continued to regulate all forms of asbestos along with non-asbestiform

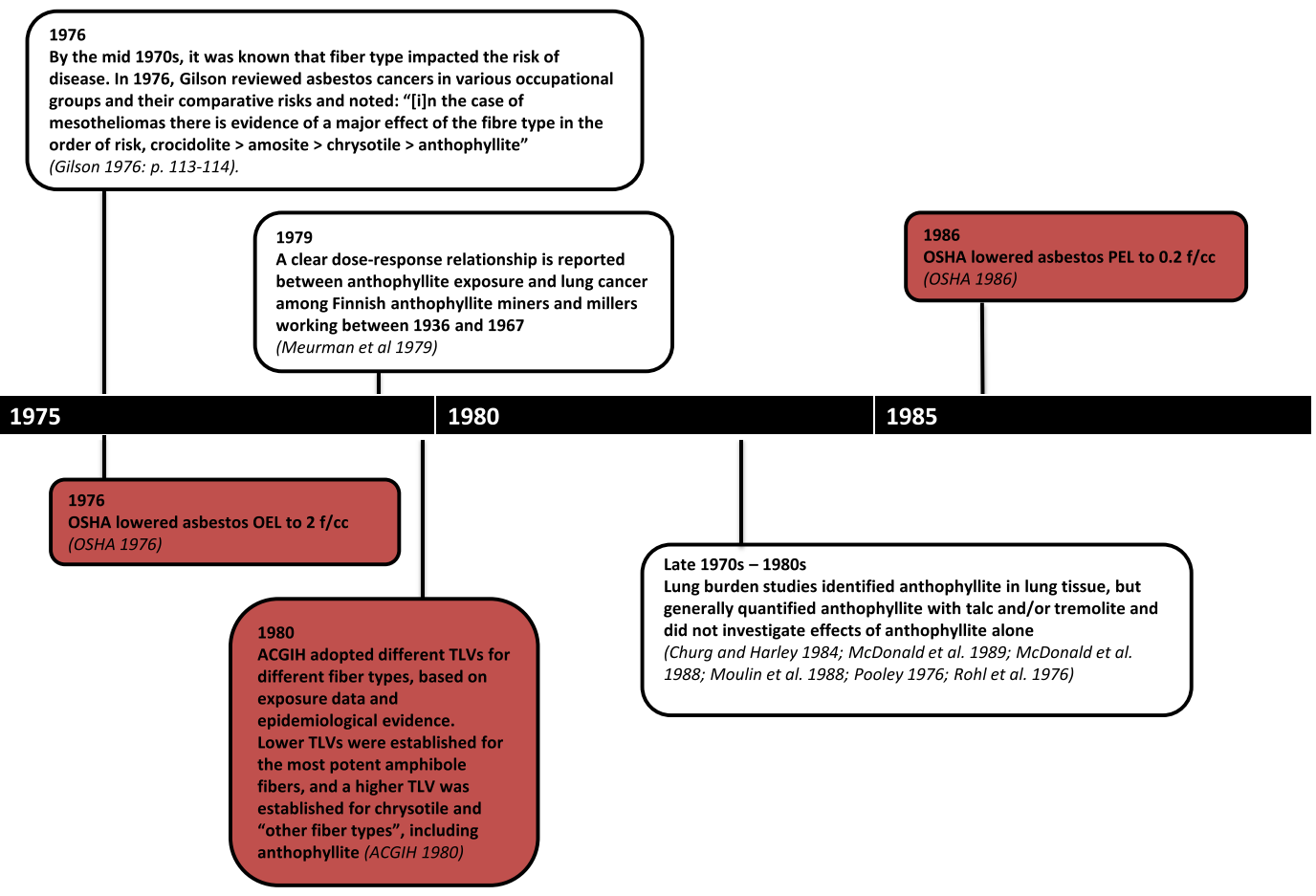

Figure 4. State of the science of anthophyllite from the mid-1970s to 1990. 
varieties of anthophyllite, tremolite, and actinolite (ATA), other agencies took different paths. In 1974, the Bureau of Mines removed non-asbestiform ATA from their asbestos standard citing that non-asbestiform did not fit the mineralogical definition for asbestos and reviewing evidence that non-asbestiform minerals did not cause carcinogenesis in laboratory animals (Bureau of Mines, 1974). Other regulatory agencies, including the U.S. Environmental Protection Agency (EPA) and the Consumer Products Safety Commission (CPSC), adopted similar stances on non-asbestiform ATA (CPSC, 1977; OSHA, 1984; USEPA, 1978). In 1978, ACGIH proposed different TLVs for different fiber types, based on exposure data and epidemiological evidence. Lower TLVs were established for the most potent amphibole fibers (crocidolite and amosite), whereas a separate TLV for chrysotile and 'other fiber types', including anthophyllite, was adopted. At this time, ACGIH found no evidence of health effects for chrysotile and other fiber exposures below $2 \mathrm{f} / \mathrm{cc}$; however, it noted that 'the exposure level of crocidolite and amosite... must be sharply lower than that of chrysotile because of their greater potential for disease production' (ACGIH, 1978b: p. 108). TLVs of 0.2 and 0.5 $\mathrm{f} / \mathrm{cc}$ for crocidolite and amosite, respectively, were proposed in 1978 and adopted in 1980, whereas the TLV for chrysotile and anthophyllite remained at $2 \mathrm{f} / \mathrm{cc}$ (ACGIH, 1978a, 1980). In 1986, OSHA further lowered its asbestos PEL to $0.2 \mathrm{f} / \mathrm{cc}$. (OSHA, 1986).

In addition to attempting to further characterize occupational asbestos exposures, lung burden studies investigating the presence of asbestos bodies as a result of low-degree and nonoccupational exposure of asbestos were also completed during this time period (Churg and Warnock, 1979a, b). Churg and Warnock (1979a) studied the lungs of 21 patients having between 300 and 9000 asbestos bodies per gram of lung tissues, an amount consistent with modest exposure to asbestos; none of the patients were 'primary asbestos workers' (Churg and Warnock, 1979a: p. 782). The majority of the lung tissue examined contained either mixed fiber types or amosite and crocidolite bodies only; however, of particular note were two patients with lung cancer whose tissue contained only anthophyllite asbestos bodies (Churg and Warnock, 1979a). The authors deduced that one of these two patients, a female with an uncharacteristically high asbestos body count for a woman, had likely been exposed through her ceramics hobby, because the clay she used contained 'substantial quantities of anthophyllite fibers' (Churg and Warnock, 1979a: p. 785). The other patient with exclusively anthophyllite asbestos bodies was a male who worked as a floor tile packer (Churg and Warnock, 1979a).

Another fiber burden analysis, conducted by Churg and Warnock (1979b), examined the asbestos content of the lungs of individuals with 100 or fewer asbestos bodies per gram of lung, which is suggestive of environmental exposure to asbestos rather than occupational exposure. The authors determined a significant difference in the proportion of anthophyllite fibers in the lungs across genders (Churg and Warnock, 1979b). Fifty-seven percent of the asbestos cores in women were anthophyllite or tremolite, but only $14 \%$ of the asbestos cores in men were identified as such. A suggested source of this exposure was through personal use of cosmetic talc, a commercially available product often naturally contaminated with anthophyllite. The authors noted that having fewer than 100 asbestos bodies per gram of lung is not believed to be enough to cause disease (Churg and Warnock, 1979b). Additional lung burden studies during this time period also identified anthophyllite in lung tissue; however, these studies generally quantified anthophyllite with talc and/or tremolite, and did not investigate the amount or effects of anthophyllite alone (Pooley, 1976; Rohl et al., 1976; Churg and Harley, 1984; McDonald et al., 1988, 1989; Moulin et al., 1988; ). The co-occurrence of these minerals naturally and in lung burden studies has made the analysis of specific fiber potency challenging.

In 1980, NIOSH published a report on environmental, morbidity and mortality studies conducted in miners and millers occupationally exposed to talc from the same upstate New York region studied previously by Kleinfeld and colleagues (NIOSH, 1980). Talc samples collected during the study were reported to contain 4.5 to $15 \%$ anthophyllite, along with 37 to $59 \%$ tremolite and small amounts of free silica. Similar to previous reports, the results from $\mathrm{NIOSH}$ demonstrated an increased risk for lung cancer mortality and non-malignant respiratory disease among these talc workers. One case of mesothelioma was identified in the study population; however, the authors noted that 'it is difficult to arrive at any conclusions regarding the etiologic role of talc exposure ... for this case' owing to the fact that the individual may have been exposed to asbestos from prior employment (NIOSH, 1980: p. 32). In subsequent years, excessive rates of mesothelioma were reported in Jefferson County, adjacent to the talc mining areas of St. Lawrence County in New York, suggesting that exposures to talc containing tremolite and anthophyllite in this region may be associated with development of mesothelioma (Vianna et al., 1981; Enterline et al., 1987).

In the mid-1970s, animal toxicological studies were published indicating that sufficient exposure to anthophyllite could induce asbestosis, mesothelioma, and lung cancer in some species (Smith and Hubert, 1974; Wagner et al., 1974). In one such study, Wagner et al. (1974) found that asbestosis, mesothelioma, and other lung tumors could be induced in Wistar rats by inhalation exposure to anthophyllite fibers at sufficient concentration and duration. In a separate study, Smith and Hubert (1974) published results indicating that $6 \%$ of hamsters injected with a single intrapleural (i.e. injection directly into the pleural cavity) dose of $10 \mathrm{mg}$ UICC anthophyllite suspended in saline developed mesotheliomas; they did not test other doses, so a dose-response analysis was not undertaken (Smith and Hubert, 1974).

Similarly, the toxicological potential of talc containing anthophyllite was evaluated in laboratory animals in the late 1970s and early 1980s (Smith et al., 1979; Stanton et al., 1981). Smith et al. (1979) injected talc samples with differing compositions into the pleural space of hamsters. No tumors were detected in the animals injected with either of two samples obtained from New York talc mines. In contrast, tumors related to treatment were found in animals included with samples containing asbestiform tremolite. In a separate evaluation, Stanton et al. (1981) implanted fibrous materials, including seven talc samples, into the pleura of female rats. No tumors above background were elicited from implanted talc samples, including one from the New York talc mining region. Importantly, these same researchers reported increased incidences of tumors in animals injected with samples of asbestiform amphibole. Neither of these studies looked at anthophyllite specifically and the talc under study contained other minerals, including non-asbestiform tremolite.

\section{State of the Art from 1990 to the Present}

Figure 6 presents a timeline of the key scientific studies and recent regulations from the 1990s until today. Prior to 1992, United States workplace airborne regulations referred to chrysotile, crocidolite, amosite, and all forms of anthophyllite, tremolite and actinolite, 
regardless of whether they were asbestiform or non-asbestiform varieties. In 1992, OSHA removed non-asbestiform actinolite, tremolite and anthophyllite (ATA) from its asbestos standard had been initially set in 1972, stating that there was inadequate evidence that non-asbestiform ATA posed a significant health risk to employees other than as a physical irritant (OSHA, 1992; ATSDR, 2001). OSHA further stated that non-asbestiform ATA would be regulated by a separate standard for 'particulates not otherwise regulated', in order to protect against 'the significant risk of respiratory effects which all particulate create at higher levels of exposure' (OSHA, 1992: p. 24328). Currently, United States workplace airborne regulations apply to chrysotile, crocidolite, amosite, and the asbestiform varieties of anthophyllite, tremolite and actinolite (OSHA, 1992; ATSDR, 2001).

In 1994, OSHA lowered its asbestos PEL to $0.1 \mathrm{f} / \mathrm{cc}$, based on the increasing awareness of the potential health risks of asbestos; it continued to regulate all asbestiform asbestos fibers together (OSHA, 1994). Conversely, ACGIH continued to recommend utilizing its 1978 fiber-specific TLVs until 1998 (ACGIH, 2001b). In 1998 , a universal TLV of $0.1 \mathrm{f} / \mathrm{cc}$ was adopted by ACGIH to 'provide a significant margin of safety in terms of asbestosis prevention which, on the weight of toxicological evidence, supports the view that the prevention of asbestosis should also minimize the risk of lung cancer [and mesothelioma]' (ACGIH, 2001b: p. 6). Other countries have continued to regulate some amphibole forms of asbestos differently (crocidolite and amosite) because of their increased potency or hazard, although anthophyllite has not been regulated as such (ACGIH, 1991; IARC, 1999).

The regulatory developments during this era occurred at the same time as ongoing epidemiological and toxicological research was performed to understand the potential health effects of anthophyllite exposure. During this time frame, additional cases of individuals having experienced potentially anthophyllite-related health outcomes were reported, and more sophisticated epidemiology studies were conducted. A 1994 study by Karjalainen found four cases of mesothelioma in a cohort of 999 Finnish anthophyllite miners and millers who were employed in the Paakkila mine, including three cases of pleural mesothelioma and one case of peritoneal mesothelioma (Karjalainen et al., 1994). Occupational histories revealed that all four patients had no asbestos exposure other than in the Paakkila mine. Those workers who were found to have mesothelioma had worked as miners or millers for 13 to 31 years, and had mesothelioma latency periods of 39 to 58 years. All four patients were smokers or ex-smokers who also had asbestosis. Three of the patients had lung tissue samples available for analysis; aside from anthophyllite fibers, only talc particles were found in the lung, and no other asbestos fiber type was detected (Karjalainen et al., 1994). The authors reported that 'the proportion of deaths from mesothelioma (about $0.8 \%$ of all male deaths) was less than the $1.5 \%$ to $18.6 \%$ that have been reported in cohorts exposed to crocidolite, amosite, tremolite, or mixtures containing these amphiboles' (Karjalainen et al., 1994: p. 214). The authors did not report a risk estimate; however, others have calculated a standardized incidence ratio (SIR) for mesothelioma of 40 for this population (95\% Cl: 10.90-102.42) (Lemen, 2006).

Subsequently, Meurman reported statistically significant increased risks for several cancers among Finnish anthophyllite miners (Meurman et al., 1994). The cohort included miners who had worked for at least 3 months, and information was gathered on their smoking habits and work history. The population was separated into two groups: 'heavily exposed', which included workers at the mill or mine, and 'moderately exposed', which included 'the rest of the personnel' (Meurman et al., 1994: p. 422). Men in the heavily exposed group who had worked for at least 3 months had an SIR of 67 (95\% Cl: 18-172) for mesothelioma, compared with the eastern Finland general population; there were no reported cases of mesothelioma in the moderately exposed group. Men in both exposure groups had an increased risk of lung cancer; the heavily exposed group had an SIR of $3.2(95 \% \mathrm{Cl}$ 2.4-4.1), and the moderately exposed group had an SIR of 2.3 (95\% Cl 1.5-3.6). Women in both exposure groups had increased numbers of observed cases of cancer of the corpus uteri compared to what was expected in the general population. The authors noted that 'the numbers of other types of cancers were so small that no clear conclusion c[ould] be drawn' (Meurman et al., 1994: p. 424). Fiber burden analysis was not used in this study.

Although Meurman and colleagues did not provide a lung fiber burden analysis for the individuals in their study, several reports published during this period did. For example, a 1994 study by Tossavainen analyzed tissue samples of 10 asbestos workers, including insulators, asbestos sprayers and asbestos product manufacturers, who died of lung cancer or mesothelioma (Tossavainen et al., 1994). Seven individuals were determined to have anthophyllite as the primary fiber type in their lungs, but the concentrations of anthophyllite, specifically were not quantified. In addition, information on other fiber types potentially detected was not presented (Tossavainen et al., 1994). The researchers proposed that anthophyllite fibers greater than $5 \mu \mathrm{m}$ in length or $0.6 \mu \mathrm{m}$ in diameter cannot be readily removed from the lungs (Tossavainen et al., 1994).

Other case reports of men diagnosed with mesothelioma have been published since 2000. However, the information provided in such reports was generally insufficient to establish a direct causal link between anthophyllite exposure and disease in the individuals. In general, reports either omitted information about the patient's other potential asbestos exposures or did not discriminate between anthophyllite and other fiber types, nor asbestiform versus non-asbestiform minerals in a lung burden analysis (Rom et al., 2001; Phillips and Murray, 2010). In a 2005 study by Dodson, one female pleural mesothelioma case (out of 54) was found to have only anthophyllite fibers in her lungs, and she reported that her only potential historical exposure to asbestos was during renovation and construction work. The authors suggested that a possible source of exposure to anthophyllite was from using talccontaining products, including cosmetics (Dodson et al., 2005). Roggli et al. (1993) examined asbestos fibers found in the lungs of 94 mesothelioma patients, but grouped tremolite, anthophyllite and actinolite fibers together in their analysis, making any specific causal relationships impossible to determine. Hull et al. (2002) examined lung fiber burden from two mesothelioma cases from New York talc workers in comparison with control cases without mesothelioma from the same area. A similar distribution of particles including talc, anthophyllite, and tremolite were found in both case and control subjects (Hull et al., 2002).

In 1999, Dodson et al. (1999) attempted to characterize the potential for asbestos exposure among the general population using lung burden data. They analyzed tissue samples from individuals living in rural settings in East Texas who were classified as having limited occupational asbestos exposure (Dodson et al., 1999). The sample group was limited to those having 20 or fewer ferruginous bodies per gram of wet lung tissue, and excluded individuals with histopathology consistent with asbestos-induced disease. Among the 33 individuals who met the inclusion criteria, anthophyllite was the second most common fiber type in lung tissue after chrysotile. Anthophyllite was the predominant fiber

sue after chrysotile. Anthophyllite was the predominant fiber 
found in seven of the cases, and was the only fiber found in three of the samples analyzed (Dodson et al., 1999). These findings suggest that anthophyllite is present in non-occupational settings, and is possibly more prevalent than previously thought. The authors noted that there are no naturally occurring anthophyllite outcrops in Eastern Texas. As these samples were taken from individuals without asbestos-induced disease, there is no indication of an increased risk of disease associated with anthophyllite at nonoccupational exposure levels among this population.

A 2002 publication by Suzuki and Yuen characterized and quantified asbestos fiber types in both lung and mesothelial tissue in mesothelioma cases. The authors noted that the types of asbestos fibers in the lung tissue versus mesothelial tissue were usually quite different, and that comparing the types of fibers and their proportion can give clarity on the fiber type most likely responsible for mesothelioma. The study reported that short, thin chrysotile fibers have the greatest ability to translocate from the lungs to other tissues; $65.8 \%$ of the chrysotile fibers counted were in mesothelial tissue, and 34.2\% in lung tissue (Suzuki and Yuen, 2002). In contrast, the majority (82.6\%) of anthophyllite fibers were found in the lung (Suzuki and Yuen, 2002). From these values, the implication based on these data is that anthophyllite's mobility between the lung and pleura may be limited compared to some other fiber types.

In recent years, anthophyllite fibers have also been identified in areas outside of the lungs and mesothelium. For example, Uibu et al. (2009) reported several types of asbestos fibers, including anthophyllite, found in the abdominal lymph nodes of Finnish males who previously worked in a variety of occupations. A 2007 report also identified anthophyllite and chrysotile fibers in the ovarian tissue of one woman (out of 46) diagnosed with ovarian cancer (Langseth et al., 2007).

In regards to toxicological studies, Aierken et al. (2014) published a study investigating the carcinogenic effects of less commonly used asbestos types. They compared intraperitoneal injections of either 0.5 or $5 \mathrm{mg}$ of tremolite and anthophyllite in rats, and found that while tremolite fibers induced malignant mesothelioma with a high incidence (96\% at the highest dose), anthophyllite induced no malignant mesothelioma in either dosing group after observing the animals for 550 days (Aierken et al., 2014). The authors reported that they used Afghan anthophyllite, which has physical characteristics that, when compared to UICC fibers, were not significantly different. They noted that the anthophyllite fibers were long (length $>20 \mu \mathrm{m}$ ) and thick (diameter$500 \mu \mathrm{m}$ ), compared to the tremolite fiber (length $<20 \mu \mathrm{m}$, diameter $<500 \mu \mathrm{m})$. They suggested that fiber diameter is a 'more critical factor' than length for mesothelial carcinogenesis by intraperitoneal injection (Aierken et al., 2014: p. 158).

Since their original publication, many aspects of the aforementioned studies concerning talc, including the characterization of anthophyllite, methods for calculating excess rates of disease, and confounding factors contributing to disease have been called into question. For example, while the content of talc from this region contains significant proportions of amphibole (primarily tremolite as well as anthophyllite at up to 10 to 15 percent), several studies have shown that the amphibole minerals, including anthophyllite, occur primarily in the non-asbestiform variety (Skinner et al., 1988; Wylie et al., 1997; Crane, 2000; ATSDR, 2001). Much of the debate on the characterization of anthophyllite is due to the inconsistent classification and identification of non-asbestiform cleavage fragments and intermediate or transitional fibers commonly found in talc mined from this region. As described by
Dan Crane (2000: p. 3), a microscopist at OSHA, intermediate or transitional fibers are fibers of anthophyllite caught in the 'mostly complete retrograde metamorphosis to talc'. These fibers may be commonly mischaracterized as anthophyllite asbestos unless subject to careful examination by multiple microscopy methods. Further, Crane has stated that these fibers defy definition, are not anthophyllite, and do not warrant regulation (Crane, 2000). A detailed discussion of the mineralogy and analytical methods for determining anthophyllite asbestos content in talc is beyond the scope of this review.

In addition, both the studies of Kleinfeld and colleagues and NIOSH (1980) demonstrating excess lung cancer mortality may have been limited by several factors, including (i) lack of information regarding smoking habits of the individuals in the cohort; (ii) failure to control for exposures from prior employment; and (iii) lack of a relationship between exposure/dose and disease development (Stille and Tabershaw, 1982; Lamm et al., 1988; Reger and Morgan, 1990; Gamble, 1993; Honda et al., 2002). Lastly, CDC and NIOSH recently evaluated the studies reporting elevated mesothelioma rates in Jefferson County, New York, adjacent to the talc mining area. In particular, NIOSH noted that the authors used the non-specific International Classification of Diseases (ICD) code for malignant neoplasms of the pleura. Data collected by NIOSH from 1999 to 2004 using the ICD-10 code specific for malignant mesothelioma demonstrate the absence of excess mesothelioma incidence in these counties (CDC, 2009; $\mathrm{NIOSH}, 2009)$.

\section{Discussion}

As is true with respect to other forms of asbestos, the early years of anthophyllite research and policy formulation were related primarily to descriptive studies of anthophyllite's minerology and to broad health-based questions. In most cases, research during these early years was not related specifically to anthophyllite but was focused on potential exposures involving nondescript dusts or on mixed asbestos exposures that may have included, but were not limited to, anthophyllite. Occupational disease in Finnish miners was first tracked in the mid-1930s. Significantly more research was conducted regarding the potential health effects of various types of asbestos by the early 1960s, and, by the mid-1970s, the first major epidemiological studies of asbestos exposure had been published. In most cases, however, these studies were either not related specifically to anthophyllite, or conclusive statements regarding the association between anthophyllite exposure and disease could not yet be established. By the early 1970s, regulatory agencies had begun placing a larger emphasis on establishing limits for asbestos exposure. In this respect, anthophyllite was generally grouped with other amphibole fibers or with asbestos in general, although ACGIH considered anthophyllite's potency to be consistent with that of chrysotile. Not until the early 1990s were more sophisticated toxicology and epidemiology studies conducted in relation to anthophyllite. As a result, only recently has a better understanding been gained of the potency differences between anthophyllite compared with other types of asbestos fibers.

In several of the published studies and case reports, researchers used lung burden analyses to estimate exposure when direct workplace or environmental measurements were not available, and there are many limitations of using lung burden values as surrogates of exposure. While fiber burden results can confirm that asbestos fibers are present in an individual's lungs, these results 
provide no information about the duration, frequency, or intensity of exposure experienced by that person. Thus, determining the source or time when a person was exposed to the fibers is not possible based solely on the presence of lung asbestos bodies. Additionally, different fibers types are cleared at different rates and these depend, at least in part, on the fiber dimensions (Dodson et al., 2005). Further, while lung burden analyses have provided information that has advanced the understanding of asbestos disease, differences in sampling, preparation and counting techniques have made comparing different studies difficult (De Vuyst et al., 1998). For all of these reasons, studies that include lung burden analyses in lieu of exposure data, although informative, are ultimately limited in their ability to determine an exposure response relationship, and especially for fibers such as anthophyllite that are rarely the only fibers present in the lungs.
This review, to our knowledge, is the most comprehensive to date regarding what has been reported about anthophyllite and its potential health effects over time. Overall, anthophyllite asbestos, including its potency and other toxicological properties, has not been well-studied compared to other forms of asbestos. We found that the state of the knowledge regarding anthophyllite, although limited, generally mirrors that of asbestos in general. Moreover, anthophyllite has been regulated much like other forms of asbestos. In other words, anthophyllite has been consistently considered a subtype of asbestos, but, most likely because of the lack of available data, it was rarely the focus of health-based studies or the subject of specific regulations regarding airborne exposure.

As discussed, the potential health implications of exposure to anthophyllite-contaminated talc products has been an area of research dating to at least the 1960s, and continues to be an active
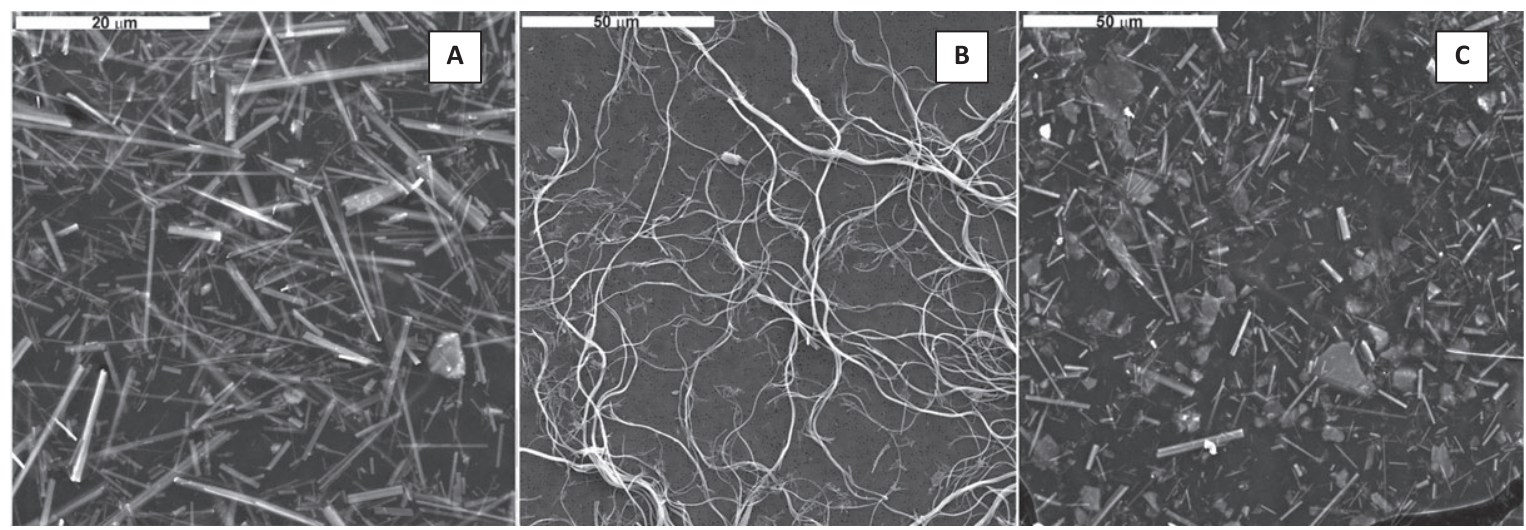

Figure 5. Comparison of UICC crocidolite (A), chrysotile (B) and anthophyllite (C).

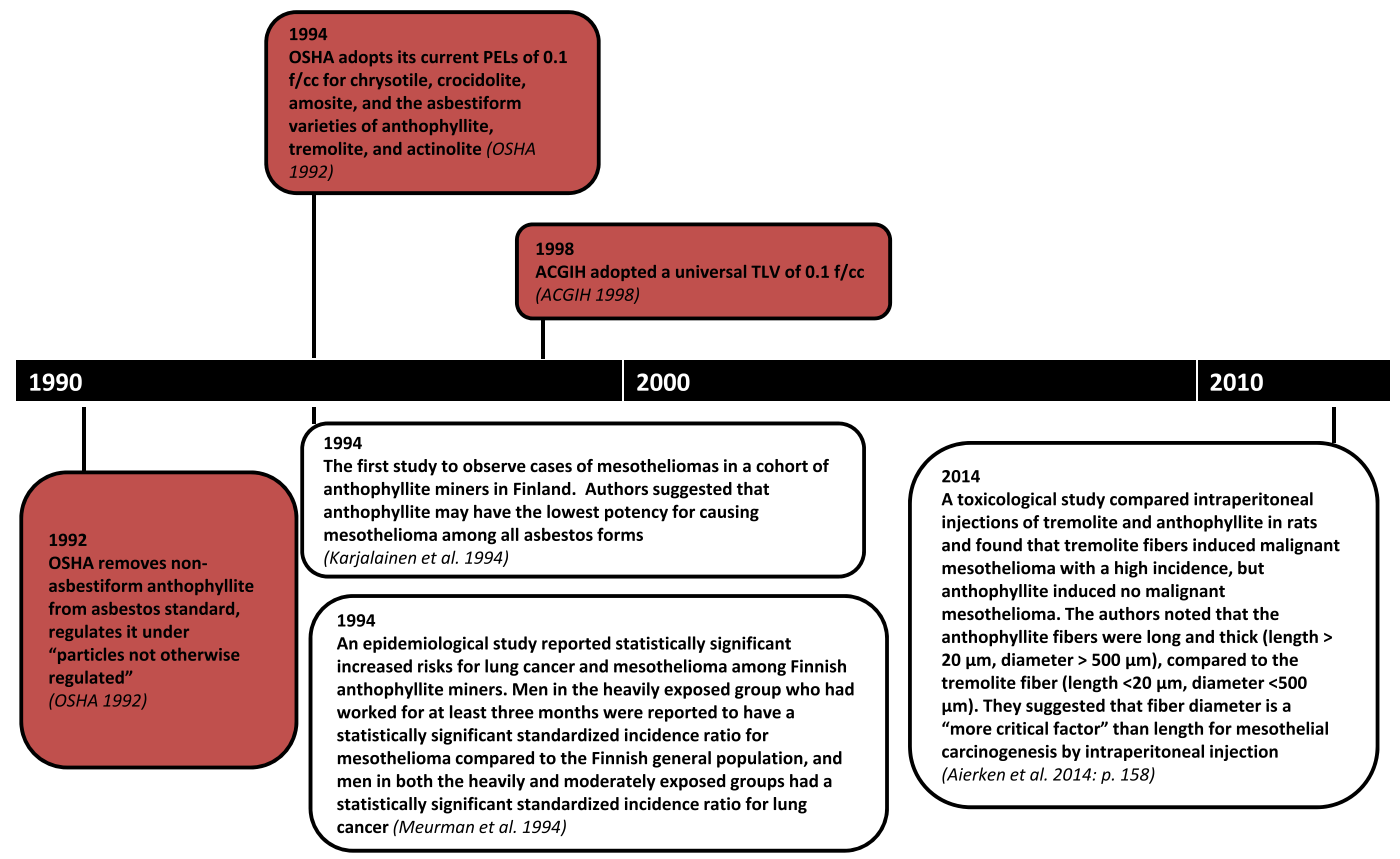

Figure 6. State of the science of anthophyllite from 1990 to the present. 
area of research and debate. Recent publications have continued to assert that exposure to talcum powder containing tremolite and anthophyllite asbestos is likely a contributing or causative factor for developing mesothelioma (Gordon et al., 2014; Gordon 2015). However, others have noted analytical challenges associated with characterizing the composition of fibers found in such products and numerous factors limiting the interpretation of epidemiology studies (Crane, 2000; Honda et al., 2002; Lee and Van Orden, 2015). In addition, the potential for talc usage contributing to anthophyllite fibers identified in lung fiber burden analyses must also be carefully examined. Talc used in cosmetic products has historically been sourced from high purity ores lacking amphibole contamination with specific properties desired by consumers (Zazenski et al., 1995; IARC, 2010). Furthermore, the cosmetic industry adopted standards in 1976 to eliminate the presence of detectable asbestiform amphiboles in talc used in cosmetic products (CTFA, 1976). Indeed, interpreting anthophyllite exposure data to accurately classify potential or historical exposure is challenging, as asbestiform and non-asbestiform varieties of anthophyllite must be differentiated. As with tremolite, this difference has the potential to influence fiber potency and poses challenges in interpreting analytical data when attempting to characterize potential occupational or environmental exposure. In addition, the interpretation of results from a mixed mineral environment such as that for New York talc, provides further difficulties in understanding the potential health implications of anthophyllite exposure.

\section{Conclusions}

Although less common than other forms of asbestos, anthophyllite is worthy of additional study from a toxicological standpoint as a result of its historical use in some consumer products. In our review, we found that some have suggested that anthophyllite may be more potent than other asbestos mineral types in causing asbestosis, but less potent than other forms of amphibole asbestos - and possibly even chrysotile - when it comes to inducing mesothelioma (Gilson, 1976; Aierken et al., 2014; Karjalainen et al., 1994), although studies have suggested that it can cause mesothelioma at sufficient doses (Karjalainen et al., 1994; Meurman et al., 1994; Wagner et al. 1974). It has been noted that '[s]tudies in Finland suggest anthophyllite almost never causes mesothelioma', and that anthophyllite appears to be the least potent fiber in causing mesothelioma (Gilson, 1976: p. 111-112). Moreover, others have reported that with respect to the Finnish cohorts, 'it seems likely that although anthophyllite fibres can induce mesotheliomas in humans, they are less potent than crocidolite or amosite' (Karjalainen et al., 1994: p. 214). Still others have suggested that anthophyllite is less potent for mesothelioma induction than crocidolite and amosite, but more potent than chrysotile (Meurman et al., 1994). Additional toxicological studies could be used to better understand the relative potency of anthophyllite asbestos, particularly as anthophyllite fibers are generally coarser and longer than other amphiboles (Langer et al., 1974; Aierken et al., 2014). Figure 5 depicts a magnified comparison of UICC crocidolite, chrysotile and anthophyllite fibers.

Additional epidemiological studies, although useful, would be more difficult to conduct, simply because of the fact that amosite and chrysotile are ubiquitous in the environment and were historically common in the marketplace. Moreover, as anthophyllite can sometimes be found as a trace element or contaminant of these other types of asbestos or talc deposits, discerning the potential health effects specific to anthophyllite is difficult from an epidemiologic standpoint; identifying populations that have been exposed exclusively to anthophyllite would be a challenge.

In summary, anthophyllite, although a recognized form of asbestos since the early $20^{\text {th }}$ century, has not been thoroughly studied from a toxicological and epidemiological perspective, particularly during early years of asbestos research. This lack of research has important implications in public health for several reasons: the toxicity of the various forms of asbestos, and how their physical and chemical properties contribute to their potency, are still being studied and debated; the content of talc, and the possible health effects associated with its use, are gaining public attention; and finally, the rates of asbestos related diseases (such as mesothelioma) are expected to increase globally over the next several years.

\section{Acknowledgements}

The authors wish to thank the RJ Lee Group for providing us with photos to present in this manuscript, and Alison Gauthier and Emma Mendelson for their assistance with research supporting the preparation of the manuscript.

\section{Conflict of interest}

All the authors are employed by Cardno ChemRisk, a consulting firm that provides scientific advice to the government, corporations, law firms, and various scientific/professional organizations. Cardno ChemRisk has been engaged by suppliers of asbestos and asbestos-containing products in various litigation matters. The study design, execution, results, and interpretation are the sole responsibility of the authors, and this manuscript was prepared and written exclusively by the authors. This work may be relied upon in scientific and medical research and litigation. Two of the authors (DJP, SHG) have served as experts in asbestos litigation. They and other authors may be called upon to serve as expert witnesses in future asbestos litigation.

\section{References}

ACGIH. 1978a. TLVs Threshold Limit Values for chemical substances and physical agents in the workroom environment with intended changes for 1978. American Conference of Governmental Industrial Hygienists (ACGIH): Cincinnati, $\mathrm{OH}$.

ACGIH. 1978b. Transactions Of The Fortieth Annual Meeting of the American Conference of Governmental Industrial Hygienists. Los Angeles, CA: May 7-12, 1978.

ACGIH. 1980. Documentation of the Threshold Limit Values. Fourth edition. American Conference of Governmental Industrial Hygienists (ACGIH): Cincinnati, $\mathrm{OH}$.

ACGIH. 1998. Asbestos, All Forms. In Supplement to the Sixth Edition: Documentation of the Threshold Limit Values and Biological Exposure Indices Institution. American Conference of Governmental Industrial Hygienists (ACGIH): Cincinnati, $\mathrm{OH}, 1-13$.

ACGIH. 1991. Asbestos. In Documentation of the Threshold Limit Values and Biological Exposure Indices. Sixth Edition. American Conference of Governmental Industrial Hygienists (ACGIH): Cincinnati, OH; 89-94.

ACGIH. 2001a. Chronology of the ACGIH TLVs for asbestos. American Conference of Governmental Industrial Hygienists (ACGIH): Cincinnati, $\mathrm{OH}$.

ACGIH. 2001b. Asbestos, All Forms: CAS Number: 1332-21-4, TLV. American Conference of Governmental Industrial Hygienists: Cincinnati, $\mathrm{OH}$.

Aierken D, Okazaki Y, Chew SH, Sakai A, Wang Y, Nagai H, Misawa N, Kohyama N, Toyokuni S. 2014. Rat model demonstrates a high risk of tremolite but a low risk of anthophyllite for mesothelial carcinogenesis. Nagoya J. Med. Sci. 76(1-2): 149-160. 
ATSDR. 2001. Toxicological profile for asbestos. U.S. Department of Health and Human Services (DHHS), Public Health Service, Agency for Toxic Substances and Disease Registry (ATSDR): Atlanta, GA.

Botham SK, Holt PF. 1972. Asbestos-body formation in the lungs of rats and guinea-pigs after inhalation of anthophyllite. J. Pathol. 107(4): 245-252.

Bowles O. 1955. Asbestos Industry. Bulletin 552, Bulletin (United States. Bureau of Mines). US Govt. Print. Off: Washington, D.C.

Brachmann D. 1940. Asbestose bei bremsbandschleifern und bohrern [Asbestosis in brake-belt grinders and drillers]. In Arbeitsschutz [Labor Safety, Accident Prevention and Industrial Hygiene, Separate edition of the Reich Labor Journal, Published by the Reich Ministry and the Reich Assurance Office in cooperation with the Office for Ind....; 172-174.

Bureau of Mines. 1974. 39 FR Part 55 - Health and Safety Standards - Metal and Nonmetallic Open Pit Mines. Fed. Reg 39: 24316-24329 .July 1, 1974

CDC. 2009. Malignant mesothelioma mortality-United States, 1999-2005. MMWR Morb. Mortal. Wkly Rep. 58(15): 393-396.

Churg A, Harley RA. 1984. Long fibre asbestos in a chrysotile textile worker. Lancet 1(8381): 845.

Churg A, Warnock ML. 1979a. Analysis of the cores of asbestos bodies from members of the general population: patients with probable low-degree exposure to asbestos. Am. Rev. Respir. Dis. 120(4): 781-786.

Churg AM, Warnock ML. 1979b. Analysis of the cores of ferruginous (asbestos) bodies from the general population. III. Patients with environmental exposure. Lab Invest. 40(5): 622-626.

Cooke WE. 1924. Fibrosis of the lungs due to the inhalation of asbestos dust. Br. Med. J. 2(3317): 147.

Cooke WE. 1927. Pulmonary asbestosis. Br. Med. J. 2: 1024-1025.

CPSC. 1977. Consumer Patching Compounds and Artificial Emberizing Materials (Embers and Ash) Containing Respirable Free-Form Asbestos. Banned Hazardous Products. Fed. Reg. 42(241): 63354-63365. Wahington, D.C.: Consumer Product Safety Commission (CPSC). December 15, 1977

Crane, D. T. 2000. Background information regarding the analysis of industrial talcs, edited by U.S. Department of Labor Occupational Safety and Health Administration: OSHA.

CTFA. 1976. CFTA Method J 4-1. In Asbestiform Amphibole Minerals in Cosmetic Talc. Part I: X-Ray Diffraction Method, Part II: Optical Microscopy and Dispersion-Staining Method. The Cosmetic, Toiletry and Fragrance Association: Washington, D.C.

De Vuyst $\mathrm{P}$, Karjalainen A, Dumortier P, Pairon JC, Monso E, Brochard P, Teschler H, Tossavainen A, Gibbs A. 1998. Guidelines for mineral fibre analyses in biological samples: Report of the ERS Working Group. European Respiratory Society. Eur. Respir. J. 11(6): 1416-1426.

Dodson RF, Graef R, Shepherd S, O'Sullivan M, Levin J. 2005. Asbestos burden in cases of mesothelioma from individuals from various regions of the United States. Ultrastruct. Pathol. 29(5): 415-433.

Dodson RF, Williams MG, Huang J, Bruce JR. 1999. Tissue burden of asbestos in nonoccupationally exposed individuals from east Texas. Am. J. Ind. Med. 35(3): 281-286.

Doll R. 1955. Mortality from lung cancer in asbestos workers. Br. J. Ind. Med. 12(2): 81-86.

Donnelly J. 1936. Pulmonary asbestosis: incidence and prognosis. J. Ind. Hyg. Toxicol. 18(41): 222-228.

Dreessen WC, Dallavalle JM, Edwards TI, Miller JW, Sayers RR. 1938. A Study of Asbestosis in the Asbestos Textile Industry, Public Health Bulletin No. 241. August 1938. U.S. Treasury Department, Public Health Service, National Institute of Health, Division of Industrial Hygiene: Washington, D.C.

Enterline PE, Hartley J, Henderson V. 1987. Asbestos and cancer: a cohort followed up to death. Br. J. Ind. Med. 44(6): 396-401.

Fulton WB, Dooley A, Matthews JL, Houtz RL. 1935. Asbestosis: Part II: The nature and amount of dust encountered in asbestos fabricating plants, Part III: The effects of exposure to dust encountered in asbestos fabricating plants on the health of a group of workers. In Industrial Hygiene Section, Special bulletin No. 42. Bureau of Industrial Standards, Commonwealth of Pennsylvania Dept. of Labor and Industry: Harrisburg, PA; 1-35. September 20

Gamble JF. 1993. A nested case control study of lung cancer among New York talc workers. Int. Arch. Occup. Environ. Health 64(6): 449-456.

George AW, Leonard RD. 1939. An x-ray study of the lungs of workmen in the asbestos industry, covering a period of ten years. Radiol. 33(2): 196-202.

Gibbs GW, Berry G. 2008. Mesothelioma and asbestos. Regul. Toxicol. Pharmacol. 52(1 Suppl): S223-S231.

Gilson JC. 1976. Asbestos cancers as an example of the problem of comparative risks. IARC Sci. Publ. 13: 107-116.
Gordon RE. 2015. Response to RE: Gordon R, Fitzgerald S, and Millette J. Asbestos in commercial cosmetic talcum powder as a cause of mesothelioma in women. Int J Occup Environ Health. 2014;20(4): 318-332. Int. J. Occup. Environ. Health 21(4): 342-346.

Gordon RE, Fitzgerald S, Millette J. 2014. Asbestos in commercial cosmetic talcum powder as a cause of mesothelioma in women. Int. J. Occup. Environ. Health 20(4): 318-332

Holt PF, Mills J, Young DK. 1966. Experimental asbestosis in the guinea-pig. J. Pathol. Bacteriol. 92(1): 185-195.

Holt PF, Young DK. 1967. The mechanism of production of asbestos bodies from anthophyllite fibres. J. Pathol. Bacteriol. 93(2): 696-699.

Home Office. 1935. Memorandum on the industrial diseases of silicosis and asbestosis. February. His Majesty's Stationery Office: London.

Honda Y, Beall C, Delzell E, Oestenstad K, Brill I, Matthews R. 2002. Mortality among workers at a talc and mining facility. The Annals of Occupational Hygiene 46(7): 575-585.

Hull MJ, Abraham JL, Case BW. 2002. Mesothelioma among Workers in Asbestiform Fiber-Bearing Talc Mines in New York State. The Annals of Occupational Hygiene 46(suppl_1): 132-135.

Huuskonen MS, Ahlman K, Mattsson T, Tossavainen A. 1980. Asbestos disease in Finland. J Occup Med. 22(11): 751-754.

IARC. 1999. ASB Asbestos. In IARC Monographs on the Evaluation of the Carcinogenic Risk of Chemicals to Man. Supplement 7, IARC (ed). International Agency for Research on Cancer: Lyon; 8-8.

IARC. 2010. Talc. In IARC Monographs on the Evaluation of Carcinogenic Risks to Humans. Volume 93, Carbon Black, Titanium Dioxide, and Talc, IARC (ed). WHO: Lyon; 277-413.

Karjalainen A, Meurman LO, Pukkala E. 1994. Four cases of mesothelioma among Finnish anthophyllite miners. Occup. Environ. Med. 51(3): 212-215.

Kiviluoto R. 1960. Pleural calcification as a roentgenologic sign of non-occupational endemic anthophyllite-asbestosis. Acta Radiol. Suppl. 194: 1-67.

Kiviluoto R. 1965. Pleural plaques and asbestos: further observations on endemic and other nonoccupational asbestosis. Ann. N. Y. Acad. Sci. 132(1): 235-239.

Kiviluoto R, Meurman L. 1970. Results of asbestos exposure in Finland. In Pneumoconiosis; Proceedings of the International Conference, Johannesburg, 1969, Shapiro HA (ed). Oxford University Press: New York; 190-196.

Kleinfeld M, Messite J, Kooyman O, Zaki MH. 1967. Mortality among talc miners and millers in New York State. Arch. Environ. Health 14(5): 663-667.

Kleinfeld M, Messite J, Zaki MH. 1974. Mortality experiences among talc workers: A follow-up study. J Occup Med. 16(5): 345-349.

Lamm SH, Levine MS, Starr JA, Tirey SL. 1988. Analysis of excessive lung cancer risk in short-term employees. Am. J. Epidemiol. 127(6): 1202-1209.

Langer AM, Mackler AD, Pooley FD. 1974. Electron microscopical investigation of asbestos fibers. Environ. Health Perspect. 9: 63-80.

Langseth H, Johansen BV, Nesland JM, Kjaerheim K. 2007. Asbestos fibers in ovarian tissue from Norwegian pulp and paper workers. Int. J. Gynecol. Cancer 17(1): 44-49.

Lanza AJ, McConnell WJ, Fehnel JW. 1935. Effects of the inhalation of asbestos dust on the lungs of asbestos workers. Public Health Rep. 50(1): 1-12.

Lee R, Van Orden D. 2015. Asbestos in commercial cosmetic talcum powder as a cause of mesothelioma in women. Int. J. Occup. Environ. Health 21(4): 337-341.

Lemen RA. 2006. Epidemiology of asbestos-related disease and the knowledge that led to what is known today. In Asbestos: Risk assessment, epidemiology, and health effects, Dodson RF, Hammar SP (eds). Taylor and Francis: Boca Raton, FL; 201-308.

McDonald JC, Armstrong B, Case B, Doell D, McCaughey WT, McDonald AD, Sebastien P. 1989. Mesothelioma and asbestos fiber type: Evidence from lung tissue analyses. Cancer 63(8): 1544-1547.

McDonald JC, McDonald AD, Sebastien P, Moy K. 1988. Health of vermiculite miners exposed to trace amounts of fibrous tremolite. Br. J. Ind. Med. 45(9): 630-634.

McDonald S. 1927. Histology of pulmonary asbestosis. Br. Med. J. 2(3491): 1025-1026.

McPheeters SB. 1936. A survey of a group of employees exposed to asbestos dust. J. Ind. Hyg. Toxicol. 18(4): 229-239.

Merewether ERA, Price CW. 1930. Report on effects of asbestos dust on the lungs and dust suppression in the asbestos industry. Part I and II. His Majesty's Stationery office: London.

Meurman L. 1966. Asbestos bodies and pleural plaques in a Finnish series of autopsy cases. Acta Pathol Microbiol Scand. (Suppl 181): 1-107.

Meurman LO, Kiviluoto R, Hakama M. 1973. Mortality and morbidity of employees of anthophyllite asbestos mines in Finland. In Biological Effects 
of Asbestos: Proceedings of a Working Conference Held at the International Agency for Research on Cancer, Lyon, France, 2-6 October 1972. IARC Scientific Publication No. 8, Bogovski P, Timbrell V, Gilson JC, Wagner JC, Davis W (eds). Lyon: International Agency for Research on Cancer; 199-202.

Meurman LO, Kiviluoto R, Hakama M. 1974. Mortality and morbidity among the working population of anthophyllite asbestos miners in Finland. Br. J. Ind. Med. 31(2): 105-112.

Meurman LO, Kiviluoto R, Hakama M. 1979. Combined effect of asbestos exposure and tobacco smoking on Finnish anthophyllite miners and millers. Ann. N. Y. Acad. Sci. 330: 491-495.

Meurman LO, Pukkala E, Hakama M. 1994. Incidence of cancer among anthophyllite asbestos miners in Finland. Occup. Environ. Med. 51(6): 421-425.

Mossman BT. 2008. Assessment of the pathogenic potential of asbestiform vs. nonasbestiform particulates (cleavage fragments) in in vitro (cell or organ culture) models and bioassays. Regul. Toxicol. Pharmacol. 52(1 Suppl): S200-S203.

Moulin E, Yourassowsky N, Dumortier P, De Vuyst P, Yernault JC. 1988. Electron microscopic analysis of asbestos body cores from the Belgian urban population. Eur. Respir. J. 1(9): 818-822.

Nicholson WJ, Selikoff IJ, Seidman H, Lilis R, Formby P. 1979. Long-term mortality experience of chrysotile miners and millers in Thetford Mines, Quebec. Ann. N. Y. Acad. Sci. 330: 11-21.

NIOSH. 1980. Occupational Exposure to Talc Containing Asbestos: Morbidity, Mortality, and Environmental Studies of Miners and Millers. DHEW (NIOSH) Publication: No. 80-115. U.S. Dept. of Health, Education, and Welfare, Public Health Service, Center for Disease Control, National Institute for Occupational Safety and Health (NIOSH): Cincinnati, $\mathrm{OH}$.

$\mathrm{NIOSH}$. 2009. NIOSH Safety and Health Topic: National Occupational Mortality Surveillance (NOMS). Cincinnati, $\mathrm{OH}$ : National Institute for Occupational Safety and Health (NIOSH). Updated May 25, 2009. http://www.cdc.gov/niosh/topics/surveillance/NOMS/method.html.

Noro L. 1968. Occupational and "Non-occupational" asbestosis in Finland. Am. Ind. Hyg. Assoc. J. 29(3): 195-201.

Nurminen M. 1972. A study of the mortality of workers in an anthophyllite asbestos factory in Finland. Work Environment Health 9: 112-118.

Oliver T. 1927. Clinical aspects of pulmonary asbestosis. Br. Med. J. 2(3491): 1026-1027.

Osborn, S. H. 1934. Asbestos dust hazards. Forty-ninth report (57th year) of the State Department of Health, State of Connecticut, Public Document No. 25. Hartford, CT. p. 507-511.

OSHA. 1972. Title 29-Labor, Chapter XVII, Part 1910: Standard for exposure to asbestos dust. Fed. Reg. 37(110): 11318-11322.

OSHA. 1976. Title 29-Labor, Chapter XVIII, Part 1910-Occupational safety and health standards, standard for asbestos exposure. Fed. Reg 41(55): 11504-11505. March 19, 1976

OSHA. 1984. 29 CFR Parts 1910: Occupational exposure to asbestos; Proposed rule and notice of hearing. Fed. Reg 49(70): 14116-14145. Washington, D.C.: U.S. Department of Labor, Occupational Safety and Health Administration (OSHA). April 10, 1984

OSHA. 1986. 29 CFR Parts 1910 and 1926: Occupational exposure to asbestos, tremolite, anthophyllite, and actinolite; Final rules. Fed. Reg. 51: 22612-22790. June 20, 1986

OSHA. 1992. 29 CFR Parts 1910 and 1926: Occupational exposure to asbestos, tremolite, anthophyllite and actinolite; Final rule. Fed. Reg. 57(110): 24310-24331. June 8, 1992

OSHA. 1994. 29 CFR Parts 1910, 1915, and 1926. RIN: 1218-AB25. Occupational exposure to asbestos; Final rule. Fed. Reg. 59(153): 40964-41162. August 10, 1994

Page RC. 1935. A study of the sputum in pulmonary asbestosis. Am. J. M. Sc. 189: 44-55.

Pancoast HK, Pendergrass EP. 1925. A review of our present knowledge of pneumoconiosis, based upon roentgenologic studies, with notes on the pathology of the condition. Am. J. Roentgenol. 24(5): 381-423.

Phillips JI, Murray J. 2010. Malignant mesothelioma in a patient with anthophyllite asbestos fibres in the lungs. Ann. Occup. Hyg. 54(4): 412-416.

Pooley FD. 1976. An examination of the fibrous mineral content of asbestos lung tissue from the Canadian chrysotile mining industry. Environ. Res. 12(3): 281-298.

Rabbitt JC. 1948. A new study of the anthophyllite series. Am. Mineral. 33(5-6): 263-323.

Raunio V. 1966. Occurrence of unusual pleural calcification in Finland. Studies on atmospheric pollution caused by asbestos. Ann Med Intern Fenn. 55(Suppl 47): 1-61.
Reger R, Morgan WK. 1990. On talc, tremolite, and tergiversation. Br. J. Ind. Med. 47(8): 505-507.

Roggli VL, Coin P. 2004. Mineralogy of asbestos. In Pathology of Asbestos Associated Diseases, Roggli V, Oury TD (eds), Second edn. Springer-Verlag: New York; 1-17.

Roggli VL, Pratt PC, Brody AR. 1993. Asbestos fiber type in malignant mesothelioma: an analytical scanning electron microscopic study of 94 cases. Am. J. Ind. Med. 23(4): 605-614.

Rohl AN, Langer AM, Wolff MS, Weisman I. 1976. Asbestos exposure during brake lining maintenance and repair. Environ. Res. 12(1): 110-128.

Rom WN, Hammar SP, Rusch V, Dodson R, Hoffman S. 2001. Malignant mesothelioma from neighborhood exposure to anthophyllite asbestos. Am. J. Ind. Med. 40(2): 211-214.

Skinner HCW, Ross M, Frondel C. 1988. Asbestos and other fibrous materials: mineralogy, crystal chemistry, and health effects. Oxford University Press: New York, NY.

Smith WE, Hubert DA, Sobel HJ, Marquet E. 1979. Biologic tests of tremolite in hamsters. In Dusts and Disease, Leman R, Dement JM (eds). Pathotox Publishers, Inc.: Park Forest South, IL; 335-339.

Smith WE, Hubert DD. 1974. The intrapleural route as a means for estimating carcinogenicity. In Experimental Lung Cancer, Karbe E, Park JF (eds). Springer: Berlin; 92-101.

Stanton MF, Layard M, Tegeris A, Miller E, May M, Morgan E, Smith A. 1981. Relation of particle dimension to carcinogenicity in amphibole asbestoses and other fibrous minerals. J. Natl. Cancer Inst. 67(5): 965-975.

Stille WT, Tabershaw IR. 1982. The mortality experience of upstate New York talc workers. J Occup Med. 24: 480-484.

Stone MJ. 1940. Clinical studies in asbestosis. Amer. Rev. Tuberc. 41: 12-21.

Suzuki Y, Yuen SR. 2002. Asbestos fibers contributing to the induction of human malignant mesothelioma. Ann. N. Y. Acad. Sci. 982: 160-176.

Teleky L. 1937. Asbestosis and its prevention (review of Windel, Arbeitsschutz 19(5):9-16, 1937). J. Ind. Hyg. Toxicol. 19(5): 112.

Tossavainen A, Karjalainen A, Karhunen PJ. 1994. Retention of asbestos fibers in the human body. Environ. Health Perspect. 102(Suppl 5): 253-255.

U.S. Congress. 1970. Public Law 91-596. Occupational Safety and Health Act of 1970. U.S. Government Printing Office: Washington, D.C.

Uibu T, Vanhala E, Sajantila A, Lunetta P, Makela-Bengs P, Goebeler S, Jantti $M$, Tossavainen A. 2009. Asbestos fibers in para-aortic and mesenteric lymph nodes. Am. J. Ind. Med. 52(6): 464-470.

USEPA. 1978. Sprayed ACM in Buildings: A guidance document. U.S. Environmental Protection Agency (EPA), Office of Air and Waste Management, Office of Air Quality Planning and Standards: Research Triangle Park, NC.

Van Gosen BS, Lowers HA, Sutley SJ, Gent CA. 2004. Using the geologic setting of talc deposits as an indicator of amphibole asbestos content. Environ. Geol. 45(7): 920-939.

Vianna NJ, Maslowsky J, Roberts S, Spellman G, Patton RB. 1981. Malignant mesothelioma; epidemiologic patterns in New York State. New York State Journal of Medicine 81(5): 735-738.

Virta RL. 1989. The Talc Industry-An Overview. Information Circular 9220. U.S. Dept. of the Interior, Bureau of Mines: Washington, DC.

Virta RL. 2005. Mineral commodity profiles: Asbestos. USGS Circular 1255-KK. U.S. Department of the Interior, U.S. Geological Survey: Washington, D.C.

Wagner JC. 1965. Epidemiology of diffuse mesothelial tumors: Evidence of an association from studies in South Africa and the United Kingdom. Ann. N. Y. Acad. Sci. 132(1): 575-578.

Wagner JC, Berry G, Skidmore JW, Timbrell V. 1974. The effects of the inhalation of asbestos in rats. Br. J. Cancer 29(3): 252-269.

Wagner JC, Sleggs CA, Marchand P. 1960. Diffuse pleural mesothelioma and asbestos exposure in the North Western Cape Province. Br. J. Ind. Med. 17: 260-271.

Wegelius C. 1947. Changes in the lungs in 126 cases of asbestosis observed in Finland. Acta Radiol. 28: 139-152.

Wood WB, Gloyne SR. 1934. Pulmonary asbestosis: A review of one hundred cases. Lancet 227(2): 1383-1385.

Wylie AG, Skinner HC, Marsh J, Snyder H, Garzione C, Hodkinson D, Winters R, Mossman BT. 1997. Mineralogical features associated with cytotoxic and proliferative effects of fibrous talc and asbestos on rodent tracheal epithelial and pleural mesothelial cells. Toxicol. Appl. Pharmacol. 147(1): 143-150.

Zazenski R, Ashton WH, Briggs D, Chudkowski M, Kelse JW, MacEachern L, McCarthy EF, Nordhauser MA, Roddy MT, Teetsel NM et al. 1995. Talc: occurrence, characterization, and consumer applications. Regul. Toxicol. Pharmacol. 21(2): 218-229. 